\title{
PENERAPAN GROUP INVESTIGATION UNTUK MENINGKATKAN KEMAMPUAN PEMECAHAN MASALAH KONTEKSTUAL BAGI PESERTA DIDIK KELAS X SMA ISLAM NUSANTARA MALANG PADA MATERI PERTIDAKSAMAAN RASIONAL DAN IRRASIONAL
}

\author{
Abdul Halim Fathani $^{1)}$, Yuli Ismi Nahdiyati Ilmi ${ }^{2)}$, Firul Santriyo ${ }^{3)}$ \\ ${ }^{1), 2)}$ Prodi Pendidikan Matematika Universitas Islam Malang, Jl. Mayjen Haryono Gg. 10 \\ No.193, Dinoyo, Kec. Lowokwaru, Kota Malang, Jawa Timur, Indonesia \\ ${ }^{3)}$ SMA Islam Nusantara Malang, Jl. Mayjen Haryono XXI/30, Dinoyo, Kec. Lowokwaru, Kota \\ Malang, Jawa Timur, Indonesia \\ fathani@unisma.ac.id,yuliismi.ni@unisma.ac.id, irulputro@gmail.com
}

\begin{abstract}
This study aims to describe the application of group investigation in improving contextual problem solving in the material rational and irrational inequality of class $\mathrm{X}$ students of senior high school Islam Nusantara Malang. This research was conducted on the basis of preliminary tests that have been given before the action of learning. These results indicate a lack of student interest in mathematics, as well as an understanding of mathematical concepts that need to learn rational and irrational inequalities also show less satisfaction. This research is a class action research, which consists of 2 cycles. The subjects of this study consisted of 10 students, with 7 students from the Social Sciences major, and 3 students majoring in Natural Sciences. The research instrument uses question sheets and observation sheets. Data analysis techniques by calculating the completeness of student learning outcomes. The first cycle shows the completeness of student learning outcomes that is equal to $60 \%$ of 10 students. Furthermore, in the second cycle increased completeness of student learning outcomes to $80 \%$. So it can be concluded that the Group Investigation is proven to be able to improve the contextual problem solving in the matter of rational and irrational inequality.
\end{abstract}

Keywords: Group Investigation, contextual problem solving, rational and irrational inequality

\begin{abstract}
Abstrak
Penelitian ini bertujuan untuk mendeskripsikan penerapan group investigation dalam meningkatkan pemecahan masalah kontekstual pada materi pertidaksamaan rasional dan irasional dari siswa kelas $\mathrm{X}$ SMA Islam Nusantara Malang. Penelitian ini dilaksanakan dengan dasar tes pendahuluan yang telah diberikan sebelum tindakan model pembelajaran. Hasil tersebut menunjukan kurangnya minat siswa pada matematika, serta pemahaman dasar-dasar matematika yang perlu untuk mempelajari pertidaksamaan rasional dan irasional juga menunjukkan kurang memuaskan. Penelitian ini merupakan penelitian tindakan kelas, yang terdiri dari 2 siklus. Subjek penelitian ini terdiri dari 10 siswa, dengan 7 siswa dari jurusan IPS, dan 3 siswa jurusan IPA. Instrumen peneltiian menggunakan lembar soal dan lembar observasi. Teknik analisis data dengan menghitung ketuntasan hasil belajar siswa. Siklus pertama menunjukkan ketuntasan hasil belajar siswa yaitu sebesar 60\% dari 10 siswa. Selanjutnya, pada siklus kedua meningkat ketuntasan hasil belajar siswa menjadi $80 \%$. Sehingga dapat disimpulkan bahwa Group Investigation terbukti dapat meningkatkan pemecahan masalah kontekstual pada materi pertidaksamaan rasional dan irasional.
\end{abstract}

Kata Kunci : Group Investigation, pemecahan masalah kontekstual, pertidaksamaan rasional dan irasional 
Cara Menulis Sitasi: Fathani, A., H., Ilmi, Y., I., N., \& Santriyo, F. (2020). Penerapan Group Investigation untuk meningkatkan Kemampuan Pemecahan Masalah Kontekstual bagi Peserta Didik Kelas X SMA Islam Nusantara Malang pada Materi Pertidaksamaan Rasional dan Irrasional. Jurnal Edukasi dan Sains Matematika (JES-MAT), 6(1). Maret 2020, halaman $1-10$.

\section{PENDAHULUAN}

Dalam rangka meningkatkan kualitas mutu pendidikan di Indonesia, pemerintah terus melakukan berbagai upaya, di antaranya adalah penyesuaian kurikulum, sampai saat ini yang terakhir yaitu kurikulum K-13. Perubahan-perubahan kurikulum terutama pada jenjang sekolah yang terjadi bertujuan agar pendidikan di Indonesia berkembang dan maju mengikuti negara-negara yang telah berhasil dalam dunia pendidikan, contohnya negara yang mencolok dalam pendidikan yaitu Finlandia.

Pendidik, siswa, dan kurikulum merupakan peran penting dalam membentuk pembelajaran yang bermakna (Eggen dan Kauchack, 2011). Beberapa upaya yang digunakan guru untuk mengubah agar tercipatanya pembelajaran yang berpusat pada siswa berjalan sukses dalam kelas. Salah satu contoh upaya guru agar terciptanya pembelajaran yang berpusat pada siswa yaitu dengan mencoba strategi pembelajaran yang inovatif.

Pemilihan model pembelajaran yang menarik menentukan keberhasilan susksesnya pembelajaran di kelas dengan menyesuaikan karakter siswa dalam kelas. Namun, berdasarkan studi pendahuluan oleh peneliti di kelas X SMA Islam Nusantara Malang, siswa sering tidak fokus dalam pembelajaran, contohnya saja ada salah satu siswa yang sering bermain HP pada saat guru menjelaskan materi. Kemungkinan penyebab dari permasalahan ini yaitu kurangnya penggunaan model pembelajaran yang inovatif oleh guru, sehingga mengakibatkan minimnya minat siswa dalam pemecahan masalah pada pertidaksamaan linear.

Permasalahan lain yang dialami siswa kelas X SMA Islam Nusantara Malang, yaitu kurangnya pemahaman dasar terkait pertidaksamaan rasional dan irrasional, sehingga rata-rata nilai siswa dalam materi tersebut masih kurang memuaskan. Menurut Idris (2009), pemahaman konsep tidak bisa diartikan hanya mengingat saja atau mengikuti prosedur dalam penyelesaian soal, tetapi perlu pembuktian, membedakan mana yang contoh atau yang bukan contoh, menggeneralisasikan, menganalogikan, mengaplikasikan, dan merepresentasikan konsep. Sehingga dengan jaringan konsep yang melibatkan dari beberapa konsep satu dengan konsep lain membuat satu kesatuan dalam pemahaman konsep yang memiliki makna masing-masing pada tiap materi. Contohnya saja dalam pertidaksamaan rasional ternyata ada pertidaksamaan linear yang sebelumnya harusnya sudah mereka pelajari, jadi perlu ada pemahaman konsep dulu tentang pertidaksamaan linear, sehingga membentuk satu kesatuan dalam pemecahan masalah pada pertidaksamaan rasional. Pada materi pertidaksamaan rasional dan irasional terdapat juga soalsoal pemecahan masalah kontekstual. Pemecahan massalah kontekstual adalah pemecahan masalah yang ada dalam kehidupan.

Kemampuan pemecahan masalah merupakan kemampuan yang sangat dalam pembelajaran matematika (Aini, 2016). 
Kemampuan matematika siswa perlu merujuk tidak hanya untuk perhitungan dasar, tetapi juga bagaimana menggunakannya untuk menganalisis masalah yang kompleks dan memperkirakan efisiensi cara yang berbeda dari pemecahan masalah yang ada dalam kehidupan (Cai \& Steven (2005); Edward \& Jinfa, 2005; Magen, 2016).

Beberapa peneliti terdahulu telah melakukan penelitian untuk meningkatkan kemampuan pemecahan masalah diantaranya, Aini (2016), melakukan upya peningkatan pemecahan masalah melalui pembelajaran open-ended. Firdaus (2019), melalukan upaya peningkatan pemecahan masalah melalui pembelajaran probing promting. Akhyar \& Rokhmah (2018), melakukan upaya peningkatan kemampuan pemecahan masalah matematis siswa melalui model pembelajaran Knisley berbasis masalah. Berdasarkan beberapa penelitian terdahulu, yang berupaya meningkatkan kemampuan pemecahan masalah, para peneliti tersebut menggunakan model pembelajaran inovatif sebagai upaya untuk meningkatkan kemampuan pemecahan masalah matematis siswa.

Salah satu model pembelajaran inovatif yang diduga dapat memfasilitasi peningkatan kemampuan pemecahan masalah model pembelajaran kooperatif Group Investigation. Menurut Aini (2016), untuk meningkatkan kemampuan pemecahan masalah diperlukan pembelajran yang membangun kegiatan interaktif antara siswa dengan matematika. selai itu, aktivitas pemecahan masalah adalah salah satu hal yang berhubungan dengan kesenangan terhadap matematika (Brown et all, 2007).
Group Investigation merupakan model pembelajaran yang menuntut siswa untuk memiliki kemampuan yang baik dalam berkomunikasi maupun dalam keterampilan proses (Nurhadi dan Sanduk 2003). Hal tersebut menunjukkan bahwa melalui group investigation siswa aktif ddalam proses pembelajaran. Menurut Firdaus (2019), 77,2\% kemampuan pemecahan masalah dipengaruhi oleh keaktifan siswa dalam proses pembelajaran. Dengan pembelajaran berkelompok meningkatkan rasa sosial antar siswa yang menumbuhkan motivasi dan semangat siswa dalam pembelajaran. Hal tersebut menurut Praptiwi dan Handika (2012) merupakan kelebihan dalam model pembelajaran tersebut. Bermula siswa berkelompok untuk merencanakan, menentukan topik, hingga menentukan cara yang mereka gunakan dalam pemecahan masalah.

Terdapat beberapa peneliti terdahulu yang menggunakan model pembelajaran gropu investigation dalam pembelajaran matematika, diantaranya Hija, dkk (2016), rahman dan Sunaryo (2016). Rahman dan Sunaryo (2016), mengkaji efektifitas model pembelajaran kooperatif tipe group investigasi terhadap hasil belajar siswa, sedangkan Hija dkk (2016) mengkaji pengaruh model pembelajaran group investigation (GI) terhadap kemampuan pemecahan masalah matematis siswa pada materi peluang kelas X MIPA.

Berdasarkan paparan latar belakang masalah di atas, peneliti tertarik untuk mengkaji penerapan group investigation dalam meningkatkan pemecahan masalah kontekstual pada materi pertidaksamaan rasional dan irasional dari siswa kelas $\mathrm{X}$ SMA Islam Nusantara Malang pada materi pertidaksamaan rasional dan irrasional. 


\section{LANDASAN/KAJIAN TEORI}

\section{Group Investigation}

Group investigation adalah model pemebalajran yang dikembangkan oleh Sharan-Sharan pada tahun 1976. Model pembelajaran ini menekankan pada pilihan dan kontrol siswa dibandingkan menerapkan beragai teknik pengajaran di kelas. Perencanaan pengorganisasian kelas pada model kooperatif Group investigation adalah dengan dibentuknya kelompok oleh siswa sendiri. Setiap kelompok beranggotakan 2 sampai 6 orang, kemudian tiap kelompok memilih subtopik dari keseluruhan unit materi (pokok bahasan) yang akan dipelaajari, kemudian setiap kelompok membuat atau menghasilkan laporan kelompok. Selanjutnya, setiap kelompok mempresentasikan atau memamerkan laporannya kepada seluruh kelas, untuk berbagi dan saling tukar informasi temuan mereka.

Berikut sintak model pembelajaran group investigation menurut Sharan \& Sharan (1989) yaitu (1) Identifying the topic to be investigated and organizing students into research groups (menentukan topik), (2) Planning the investigation in groups (perencanaan kooperatif), (3) Carrying out the investigation (implementasi), (4) Preparing a final report (analisis dan sintesis), (5) Presenting the final report (presentasi hasil final), (6) Evaluation (evaluasi).

\section{Kemampuan Pemecahan Masalah}

Menurut Undang-undang No. 22 tahun 2006, pemecahan masalah yang meliputi kemampuan memahami masalah, merancang model matematika, menyelesaikan model dan menafsirkan solusi yang diperoleh.

Menurut Hamzah dan Muhlisrarini (2013) pemecahan masalah adalah penyelesaian untuk menjembatani antara apa yang diketahui dan apa yang dipertanyakan dari suatu soal. Kemampuan pemecahan masalah juga ditunjang oleh kemampuan menguasai sejumlah konsep dan prinsip dalam matematika. Hal ini ditegaskan oleh NCTM (2000) bahwa para siswa harus belajar matematika dengan pemahaman, secara aktif membangun pengetahuan baru dari pengalaman dan pengetahuan sebelumnya. Pembelajaran yang bertujuan untuk membentuk kemampuan pemecahan masalah lebih menekankan pada penyajian materi pembelajaran dalam bentuk penyajian masalah yang menuntun proses pemecahan masalah.

Langkah-langkah dalam pemecahan masalah menurut John Dewey (Sukasno, 2006) adalah 1) Merasakan adanya kesulitan atau permasalahn yang menuntut pemecahan; 2) Merumuskan dan membatasi masalah sebagai dasar untuk mencari fakta sebagai upaya untuk menemukan pemecahannya; 3) Mengajukan rumusan kesimpulan sementara terhadap pemecahan masalah (hipotesis) yang akan diuji kebenarannya berdasar fakta atau argumentasi yang nalar; 4) Menguji hipotesis yang diajukan dengan suatu bukti yang dapat menjadi dasar untuk menolak atau menerima kebenaran hipotesis yang dibuat; 5) Merumuskan kesimpulan berdasarkan hasil pengujian hipotesis.

Melalui langkah - langkah pemecahan masalah tersebut, proses pembelajaran di kelas dapat membiasakan siswa untuk menghadapi dan memecahkan masalah secara terampil dan dapat diterapkan dalam kehidupan sehari-hari. 


\section{METODE PENELITIAN}

\section{Jenis Penelitian}

Penelitian ini meupakan penelitian tindakan kelas (PTK). dengan tujuan untuk mendeskripsikan penerapan model pembelajaran group investigation pada materi aplikasi pertidaksamaan rasional dan irrasional untuk meningkatkan pemecahan masalah kontekstual pada siswa kelas $\mathrm{X}$ SMA Islam Nusantara Malang. Jenis penelitian yang dilaksanakan yaitu penelitian tindakan kelas (PTK). Penelitian ini terdiri dari dua siklus dimana tiap siklus ada empat tahapan, yaitu: perencanaan, pelaksanaan, observasi, dan refleksi.

\section{Waktu dan Tempat Penelitian}

Penelitian dilaksanakan pada Semester genap tahun ajaran 2018/2019. Tempat penelitian di SMA Islam Nuasantara malang.

\section{Subjek Penelitian}

Subjek penelitian ini terdiri dari 10 siswa, dengan 7 siswa dari jurusan IPS, dan 3 siswa jurusan IPA. Karena minimnya siswa untuk mata pelajaran matematika wajib semua siswa dijadikan satu kelas.

\section{Prosedur}

Tindakan pertama yang diberikan yaitu mengadakan tes pendahuluan untuk mengetahui indeks prestasi siswa dalam mata pelajaran matematika. Kemudian dilanjutkan dengan siklus pertama dan kedua yaitu dengan teknik observasi yang melakukan pengamatan langsung terhadap proses pembelajaran dan keadaan yang berkaitan pelaksanaan pembelajaran aplikasi pertidaksamaan rasional dan irrasional dengan menggunakan model Kooperatif Group Investigation. Siklus kedua ini digunakan sebagai bahan refleksi dan evaluasi pelaksanaan tindakan pada siklus kedua.

Data, Intrumen, dan Teknik Pengumpulan Data

Instrumen penelitian yang digunakan dalam penelitian ini diantaranya:

1. Lembar Soal

Soal yang kemampuan pemecahan masalah kontekstual pada materi pertidaksamaan rasional dan irrasional.

2. Lembar Observasi

Observasi berisikan form isian tentang pengamatan terhadap siswa tentang proses penerapan model pembelajaran group investigation dan kemampuan pemecahan masalah.

\section{Teknik Analisis Data}

Dalam menghitung ketuntasan hasil belajar siswa setelah penerapan Group Investigation dinyatakan dengan ketentuan yaitu: a) ketuntasan perorangan, seorangsiswa dinyatakan tuntas apabila telah mencapai $\geq 70$ dari nilai maksimal 100. b) ketuntasan klasikal, suatu kelas dikatakan tuntas apabila terdapat minimal $75 \%$ yang telah mencapai nilai $\geq 70$ dari nilai maksimal 100. Selain itu, peneliti menggunakan analisis data kemampuan proses berdasarkan tabel kriteria persentase aktivitas peserta didik sebagai berikut.

Tabel 1. Persentase Aktivitas Peserta didik

\begin{tabular}{cll}
\hline No & \multicolumn{1}{c}{ Persentase } & \multicolumn{1}{c}{ Kategori } \\
\hline 1. & $86 \%-100 \%$ & Sangat baik \\
2. & $76 \%-85 \%$ & Baik \\
3. & $60 \%-75 \%$ & Cukup \\
4. & $55 \%-59 \%$ & Kurang \\
5. & $<54 \%$ & Kurang sekali \\
\hline
\end{tabular}




\section{HASIL PENELITIAN DAN PEMBAHASAN}

Penelitian ini dilaksanakan dengan menggunakan dua siklus, sebelum siklus dimulai adapun uji pendahuluan untuk mengetahui kemampuan siswa kelas $\mathrm{X}$ SMA Islam Nusantara Malang. Pada uji pendahuluan ini peneliti memberikan soalsoal yang berkaitan dengan materi aplikasi pertidaksamaan rasional dan irrasional. Diperoleh dari studi pendahuluan ini yaitu: (1) motivasi siswa masih cukup rendah, (2) pemahaman konsep juga terhitung rendah. Berdasarkan hasil wawancara dengan siswa, ada beberapa faktor yang menyebabkan motivasi siswa masih rendah yaitu kurangnya model pembelajaran yang variatif dalam kelas. Kemudian pemahaman mereka hanya mengingat saja dan mengikuti prosedur penyelesaian tanpa mereka memahaminya.

Selama pemberian tindakan melalui 4 kali pertemuan terlihat siswa mulai ada peningkatan ketertarikan dalam mata pelajaran matematika khususnya pertidaksamaan rasional dan irasional beserta aplikasinya. Melalui model pembelajaran group investigation siswa dapat dengan mudah mengatur tahapantahapan penyelesaian dalam LKPD yang telah diberikan, mulai dari perencanaan sampai evaluasi pengerjaan pada soal yang telah diberikan. Hasil tindakan pada siklus kedua telah memenuhi keberhasilan tindakan sehingga tidak perlu adanya siklus berkelanjutan.

Pada pemberian tindakan peneliti membentuk kelompok menjadi 4, dengan masing-masing kelompok terdapat siswa yang berkemampuan rendah, sedang, dan tinggi. Kemudian peneliti memberi LKPD pada tiap kelompok mengenai pertidaksamaan rasional dan irasional beserta aplikasinya. Setelah pembagian LKPD, peneliti memberikan arahan cara pengerjaan LKPD dan meminta siswa memahami materi dan menyelesaikan masalah yang berkaitan dengan materi yang diberikan. Siswa berkelompok mengerjakan LKPD tersebut dengan kerja sama anatar satu sama lain. Setelah mereka menyelesaikan tugas kelompok pada LKPD, perwakilan dari tiap kelompok mempresentasikan hasil pengerjaannya. Peneliti memberikan kesempatan pada siswa yang lain untuk bertanya pada kelompok yang mempresentasikan hasil pengerjaannya. Pada tahap ini apabila siswa yang mempresentasikan mengalami kesulitan menjawab, peneliti memberikan bantuan menjawab melalui pendekatan yang dapat memunculkan ide siswa untuk menjawab pertanyaan tersebut.

Pada LKPD ini terdiri dari tiga jenis soal, yaitu latihan soal terbimbing, soal yang dikerjakan secara berkelompok, serta soal individu. Persoalan pada LKPD ini mengenai pemecahan masalah pada pertidaksamaan rasional dan irasional dalam kehidupan sehari-hari. LKPD dirancang agar mempermudah siswa mencapai tujuan pembelajaran dengan melalui model pembelajaran yang mandiri yaitu model group investigation. Model pembelajaran ini dibuat agar siswa dapat menjadi detektif dalam menyelesaikan kasus yang direpesntasikan dalam soal di LKPD. Melalui kerja sama yang baik dapat meningkatkan kemampuan komunikatif siswa serta meningkatakan motivasi dan ketertarikan siswa pada matematika didalam kelas.

Penerapan Group Investigation memiliki langkah - langkah menurut 
Sharan \& Sharan (1989) yaitu (1) Identifying the topic to be investigated and organizing students into research groups (menentukan topik), (2) Planning the investigation in groups (perencanaan kooperatif), (3) Carrying out the investigation (implementasi), (4) Preparing a final report (analisis dan sintesis), (5) Presenting the final report (presentasi hasil final), (6) Evaluation (evaluasi). Adapun hasil tindakan dengan tahapan model tersebut dapat dilihat pada tabel berikut.

Tabel 2. Hasil analisis tahapan pada model pembelajaran Group Investigation

\begin{tabular}{ccc}
\hline Unjuk Kerja & Skor Rata-rata $(\%)$ & Kategori \\
\hline Bertanya & 79,68 & Baik \\
Identifikasi topik & 80,46 & Baik \\
Perencanaan kooperatif & 85 & Baik \\
Observasi & 82,5 & Baik \\
Menggunakan alat atau & 87 & Sangat Baik \\
bahan yang diberikan & & \\
Analisis dan sintesis & 72,57 & Baik \\
Menyiapakan bahan & 78,90 & Baik \\
presentasi & & Baik \\
Kemampuan presentasi & 80,78 & Baik \\
Evaluasi atau membuat & 77 & \\
kesimpulan & &
\end{tabular}

Berdasarkan Tabel 2. tersebut diperoleh rata-rata 80,43 dengan kategori baik. Ini menunjukan bahwa model kooperatif group investigation efektif digunakan dalam pembelajaran di kelas. Selain itu kerja sama yang dibangun selama pengerjaan kelompok berjalan dengan baik dan mencapai apa yang diharapkan peneliti yaitu meningkatkan pemecahan masalah aplikasi pertdaksamaan rasional dan irasioanal dengan model pembelajaran group investigation. Hal ini sesuai dengan Payne dan Whittaker (2000) mengatakan bahwa group investigation merupakan model pembelajaran kooperatif yang membuat siswa aktif selama memberikan pendapat dan diskusi, serta dapat meningkatkan motivasi siswa dalam pemecahan masalah yang telah diberikan secara mandiri.

Dalam penelitian ini diberikan 3 kali tes, yaitu tes pendahuluan (pra siklus) untuk mengetahui siswa berkemampuan, rendah, sedang, atau tinggi, tes akhir siklus I, dan tes akhir siklus II. Bentuk tes dirangcang dengan bentuk uraian. Hal tersebut dapat dibandingan dengan menggunakan tabel berikut. Pelaksanaan tes akhir ini merupakan tes individu yang diberikan pada siswa setelah mereka mengerjakan tugas kelompok. Namun, tes kelompok ataupun individu tetap satu kesatuan dalam LKPD. 
Tabel 3. Peningkatan hasil belajar peserta didik

\begin{tabular}{|c|c|c|c|c|}
\hline \multirow{2}{*}{ No } & \multirow{2}{*}{ Kategori Hasil Belajar } & Pra & Siklus I & Siklus II \\
\hline & & Siklus & $(\%)$ & $(\%)$ \\
\hline 1 & $\begin{array}{l}\text { Tuntas, memenuhi KKM }(\geq 70) \\
\text { dari skor maksimal } 100\end{array}$ & 30 & 60 & 80 \\
\hline 2 & $\begin{array}{c}\text { Tidak Tuntas, Tidak memenuhi } \\
\text { KKM }(\leq 70) \text { dari skor maksimal } \\
100\end{array}$ & 70 & 40 & 20 \\
\hline & Total & 100 & 100 & 100 \\
\hline
\end{tabular}

Berdasarkan Tabel 3. nampak perubahan yang drastis pada pra siklus hingga siklus kedua. Siswa yang terdiri 10 orang mempermudah penghitungan statistika dalam penelitian ini. Sehingga hasil penghitungannya tidak ada nilai desimal. Saat siklus pertama siswa masih belum begitu paham dengan alur model pembelajaran yang telah diberikan, dan beberapa siswa masih kesulitan memahami konsep pemecahan masalah pada pertidaksamaan rasional. Namun, saat siklus kedua siswa mulai memahami dasardasar dalam menyelesaikan pemecahan masalah pertidaksamaan rasional dan irrasional, sehingga terlihat hasil penilaian pada tes akhir siklus kedua 8 dari 10 siswa nilai berada diatas 70 atau berada diatas KKM.

Penelitian ini merupakan penelitian tindakan kelas yang bertujuan untuk mengetahui bagaimana penerapan model pembelajaran Group Investigation pada pemecahan masalah pertidaksamaan rasional dan irasional dalam kehidupan sehari-hari, selain itu juga ingin mengetahui aktivitas proses pemebelajaran dengan penerapan model tersebut, dan terakhir mengetahui bagaimana hasil belajar peserta didik selama penerapan. Berdasakan pemantauan selama tindakan, peserta didik berantusias untuk menggunakan model pembelajaran Group Investigation dan membuat siswa bersemangat dalam mengikuti pembelajaran di kelas. Sehingga hasil belajar yang diperoleh terdapat kenaikan pada tiap pra siklus hingga tes akhir siklus kedua. Ketika siswa bersemangat dan antusis belajar hal tersebut menunjukka siswa memiliki kesenangan dalam proses pembelaajran matematika dengan model group investigation. Menurut (Brown et all, 2007) aktivitas pemecahan masalah adalah salah satu hal yang berhubungan dengan kesenangan terhadap matematika.

Pada saat studi pendahuluan atau pra siklus diperoleh hanya 3 siswa yang memiliki nilai kurang. Dengan adanya tindakan pada siklus I, hasil belajar mengalami peningkatan hampir $50 \%$ dari sebelumnya. Kendala utama pada siklus I ini, siswa masih penyesuaian dalam menggunakan model pembelajaran Group Investigation, sehingga manajemen waktu yang digunakan melebihi batas jam pelajaran. Oleh karena itu, pada siklus I tidak ada siswa dari kelompok lain yang mengajukan pertanyaan atau memberikan pendapat untuk menanggapi kelompok yang merepresentasikan hasil diskusinya.

Menindaklanjuti kendala yang terjadi pada siklus I, manejemen waktu semakin diperhatikan, siswa tiap kelompok 
dapat memberikan komentar atau pertanyaan mengenai presentasi kelompok yang telah maju. Sehingga dengan interaksi ini menigkatkan kemampuan komunikatif siswa dalam penyelesaian masalah pertidaksamaan rasional dan irasional dalam kehidupan sehari-hari. Hal tersebut juga berpengaruh pada hasil belajar individu yang meningkat menjadi 8 siswa yang mendapatkan nilai lebih dari 70 . Sedangkan dua siswa lainnya memiliki nilai diatas 60, tetapi kurang dari 70 . Namun untuk motivasi siswa mengalami peningkatan saat pemberian tindakan di sklus I sampai siklus ke II. Peningkatan mootivasi terlihat selama pelaksanaan pembelajaran yaitu perhatian siswa sangat antusias keika siswa lain yang mempresentasikan hasil diskusinya. Hal tersebut menunjukkan bahwa melalui modelpembelajaran group investigation siswa aktif ddalam proses pembelajaran. Menurut Firdaus (2019), kemampuan pemecahan masalah dipengaruhi oleh keaktifan siswa dalam proses pembelajaran.

\section{SIMPULAN DAN SARAN}

\section{Simpulan}

Berdasarkan hasil penelitisn dapat diambil kesimpulan bahwa pembelajaran kooperatif jenis Group Investigation dapat menigkatkan pemecahan masalah siswa pada materi pertdiaksamaan rasional dan irasionaldalam kehidupan sehari-hari. Selain itu, melalui model pembelajaran tersebut dapat meningkatkan motivasi siswa dalam proses pembelajaran berlangsung, serta meningkatkan kemampuan komunikatif siswa dan kerja sama siswa dalam pembelajran.

\section{Saran}

Untuk peneliti selanjutnya disarankan menggunakan jenis model lain untuk meningkatkan motivasi peserta didik dan pemecahan masalah siswa dalam menyelesaikan pertidaksamaan rasional dan irasional. Perlu adanya materi dasar sebelum memulai materi ini diberikan. Model pembelajaran kooperatif harus menyesuaikan dengan kondisi peserta didik dan suasana di kelas.

\section{DAFTAR PUSTAKA}

Aini, I., N. (2016). Upaya meningkatkan kemampuan pemecahan masalah matematika siswa melalui pendekatan open-ended. Jurnal Edukasi dan Sains Matematika (JES-MAT), 2(2), pp. $29-40$.

Brown, M. et all. (2007). "I Would Rather Die": Attitudes of 16 year olds Towards Their Future Participation in Mathematics. Proceedings of The British Society for Research into Learning Mathematics.

Cai, J., \& Steven, H. (2005). Generalized and Generative Thinking in U.S and Chinese Students' Mthematical Problem Solving and Problem Posing. Journal of mathematical Behavior, 2(1), pp. 401-21 .

Edward, A. S., \& Jinfa, C. (2005). Assessing students' mathematical problem posing. Teaching Children Mathematic, 12(3), pp. 129-135.

Eggen, P., \& Kauchak, D. (2011). Strategies and models for teachers: Teaching content and thinking skills. British Columbia: Pearson Higher Ed. Firdaus, E., F. (2019). Pengaruh keaktifan siswa dalam pembelajaran metode probing promting terhadap kemampuan pemecahan masalah matematis materi logika. Jurnal 
Edukasi dan Sains Matematika (JESMAT), 5(2), pp. 137 - 144.

Hamzah, A dan Muhlisrarini. (2013). Perencanaan dan Strategi Pembelajaran Matematika. Jakarta : PT Raja Grafindo Persada.

Hija, A., Nirawati, R., Prihatiningtyas, N., C. (2016). Pengaruh model pembelajaran group investigation (GI) terhadap kemampuan pemecahan masalah matematis siswa pada materi peluang kelas X MIPA. Jurnal Pendidikan Matematika Indonesia, 1(1), pp. 25 - 33.

Idris, N. (2009). Enhancing students' understanding in calculus trough writing. International Electronic Journal of Mathematics Education, 4(1), 36-55.

Magen, N. (2016). The Efect of Learning Srategies on Mathematical Literacy: A Comparasion Between Lower or Higher Achieving Countries. International Journal of Research in Education and Science, 2(2), pp. 306321.

NCTM. (2000). Principles and standars for school mathematics. Roston, VA: National Council of Teacher of mathematics.

Nurhadi dan Senduk, A., G. (2003). Pembelajaran Kontekstual dan Penerapannya dalam KBK. Malang : UNM.
Payne,E. \& Whittaker, L. (2000). Developing Essential Study Skills. Pearson Education. Prentice-Hall, England.

Praptiwi \& Handhika, J. (2012). Efektivitas Metode Kooperatif Tipe GI dan STAD Ditinjau Dari Kemampuan Awal. Jurnal Penelitian Pembelajaran Fisika, 3(1), pp. 41-50. Rahman, M., A \& Sunaryo. (2016). Efektifitas model pembeljaran kooperatif tipe group investigasi terhadap hasil belajar matematika siswa kelas $\mathrm{X}$ SMAN 1 Sewon Kabupaten Bantul emester genap tau ajaran 2017/2018. Prosiding Seminar Nasional Pendidikan matematika Ahmad Dahlan . pp. 728 - 733.

Sharan, Y., \& Sharan, S. (1989). Group Investigation Expands Cooperative Learning (online). tersedia:www.ascd.org/.../el_198912_ sharan.pdf.

Sukasno. (2006). Evaluasi Pembelajaran Matematika. Lubuk Linggau : STKIP-PGRI Lubuk Linggau. 